\title{
Faktor Kesulitan Guru Melaksanakan Pembelajaran Materi Struktur dan Fungsi Sel di SMA Negeri Se-Kota Bima
}

\author{
Mei Indra Jayanti \\ Program Studi Pendidikan Biologi, STKIP Bima. Jalan PiereTendeanKel. Mande Tel. Fax (0374) \\ 42801, Bima84191, Indonesia. \\ Email: meiindra15@gmail.com
}

\begin{abstract}
Abstrak
Dalam usaha mencapai tujuan pendidikan, seringkali muncul berbagai macam permasalahan yang menghambat jalannya pencapaian tujuan pendidikan sesuai dengan yang dijabarkan dalam kompetensi inti dan kompetensi dasar. Penelitian ini bertujuan untuk menganalisis faktor kesulitan guru dalam melaksanakan pembelajaran biologi pada materi struktur dan fungsi sel untuk kelas XI semester 1(gasal) di SMA Negeri se-Kota Bima. Penelitian ini adalah penelitian deskriptif dengan sampel berjumlah 10 orang guru biologi yang mengajar pada kelas XI di SMA Negeri se-Kota Bima yang berjumlah 5 sekolah. Data penelitian dikumpulkan menggunakan angket. Data diolah menggunakan analisis statistik dengan menggunakan persentase untuk menggambarkan tingkat kesulitan guru dalam melaksanakan pembelajaran biologi pokok bahasan struktur dan fungsi sel. Hasil penelitian menunjukan bahwa terdapat empat faktor kesulitan guru dalam melaksanakan pembelajaran biologi materi struktur dan fungsi sel di SMA Negeri se-Kota Bima, yaitu faktor kesukaran materi ajar, faktor pemlihan model/matode pembelajaran, faktor saran dan prasarana pembelajaran, dan faktor jenis evaluasi pembelajaran.
\end{abstract}

Kata Kunci: faktor kesulitan guru, pembelajaran biologi, struktur dan fungsi sel

\section{PENDAHULUAN}

Pendidikan yang ideal berdasarkan Undang-Undang Republik Indonesia Nomor 14 Tahun 2005 adalah sebuah bentuk upaya mencerdaskan kehidupan bangsa dan meningkatkan kualitas manusia Indonesia yang beriman, bertakwa, dan berakhlak mulia serta menguasai ilmu pengetahuan, teknologi, dan seni dalam mewujudkan masyarakat yang maju, adil, makmur, dan beradab berdasarkan Pancasila dan Undang-Undang Dasar Negara Republik Indonesia Tahun 1945. Dijelaskan dalam Ketentuan Umum Pasal 1 ayat 3 Undang-Undang Republik Indonesia Nomor 20 Tahun 2003 bahwa sistem pendidikan nasional adalah keseluruhan komponen pendidikan yang saling terkait secara terpadu untuk mencapai tujuan pendidikan nasional. Komponen inti pendidikan yang dimaksud adalah pendidik dan peserta didik dalam proses belajar mengajar, sehingga dalam hal ini guru mempunyai fungsi, peran dan kedudukan yang sangat strategis dalam menunjang sistem pembelajaran.

Fungsi pendidikan adalah membimbing peserta didik menuju pencapaian tujuan yang bernilai tinggi. Sehingga melalui pendidikan yang efektif akan dapat membawa peserta didik kepada tujuan yang diharapkan (Wahyu, 2011). Dalam pembelajaran biologi, adanya 
interaksi antara peserta didik dengan sarana dan prasarana yang tersedia di sekolah. lingkungannya merupakan hal yang tidak Khususnya pada materi-materi abstrak yang dapat dikesampingkan. Hal lain yang harus memerlukan pengamatan mikroskopis, selain disadari oleh guru dalam mengembangkan ketersediaan fasilitas laboratorium serta alat pembelajaran biologi adalah mencakup dan bahan yang memadai, juga diperlukan pengetahuan, proses investigasi/ eksplorasi, dan nilai yang dapat diaplikasikan serta dikembangkan dalam kehidupan nyata perangkat tersebut, sehingga kegiatan (Nurainun, 2014). Selama proses pembelajaran, guru berperan sebagai fasilitator. Berbagai caraa dapat dilakukan oleh guru dalam memfasiltasi proses transfer ilmu pengetahuan kepada peserta didik antara lain dengan menggunakan model-model pembelajaran yang bervariasi, mengoptimalkan dan mengkreasikan media pembelajaran, juga malakukan komunikasi dua arah serta memberikan umpan balik kepada peserta didik.

Dalam usaha mencapai tujuan pendidikan yang telah disebutkan di atas, seringkali muncul permasalahan-permasalahan yang menghambat jalannya pencapaian tujuan pendidikan yang dijabarkan dalam kompetensi inti dan kompetensi dasar. Permasalahan tersebut dapat timbul dari dalam kelas maupun dari luar kelas, baik dari guru maupun peserta didik sendiri. Pada mata pelajaran biologi, berbagai macam permasalahan yang muncul dalam kegiatan belajar mengajar dapat bersumber dari tingkat kesukaran materi ajar (pokok bahasan), kompetensi guru, dan juga 
angket pertanyaan tertutup dan angket pertanyaan terbuka. Teknik analisis data yang digunakan adalah analisis statistik dengan menggunakan persentase untuk menggambarkan tingkat kesulitan guru dalam melaksanakan pembelajaran biologi pokok bahasan struktur dan fungsi sel.

\section{HASIL DAN PEMBAHASAN}

Berdasarkan angket yang dibagikan ke guru-guru biologi yang bertindak sebagai sampel dalam penelitian ini, data yang telah terkumpul diklasifikasikan ke dalam empat bagian yang mewakili argumen guru-guru biolog terhadap faktor kesulitan gulu dalam melaksanakan pembelajaran biologi pokok bahasan struktur dan fungsi sel. Empat faktor tersebut yakni :

\section{Faktor kesukaran materi ajar}

Pokok bahasan struktur dan fungsi sel termuat dalam kurikulum 2013 yang dibebankan pada kompetensi dasar (KD) khususnya pada ranah kognitif yakni KD 3.1 Mendeskripsikan komponen kimiawi sel, struktur, dan fungsi sel sebagai unit terkecil kehidupan, mengidentifikasi organel sel melalui pengamatan; dan 3.2 Membandingkan mekanisme transpor pada membran (difusi, osmosis, transpor aktif, endositosis, dan eksositosis) dari hasil pengamatan. Sedang pada ranah psikomotorik terdapat pada KD 4.1
Melakukan pengamatan mikroskopis sel umbi lapis bawang merah dan sel epitel pipi, mengidentifikasi organel penyusunnya serta fungsinya; dan 4.2 Melakukan percobaan difusi dan osmosis dengan menggunakan umbi kentang atau batang kangkung atau batang saledri dan mengkaitkannya dengan peristiwa transport trans membran. Adapun subpokok bahasan dari kompetensi dasar tersebut meliputi sejarah penemuan sel, perbedaan sel tumbuhen dan sel hewan, organel-organel sel, dan mekanisme transport membran (Dokumen Kurikulum 2013 SMA/MA, 2013).

Dari muatan kompetensi dasar tersebut, dapat diketahui bahwa pokok bahasan struktur dan fungsi sel memuat konten mater ajar yang sangat kompleks hanya dalam 1 pokok bahasan yang dimana alokasi waktu yang umumnya dipergunakan oleh guru yakni selama lebih kurang 4 kali pertemuan (10 x 45 menit). Hal ini mengakibatkan $41,7 \%$ guru biologi SMA Negeri se-Kota Bima setuju bahwa konten materilah yang menjadi penyebab kesulitan guru dalam mengajar pokok bahasan struktur dan fungsi sel.

Selama 4 kali pertemuan tersebut, guru beserta peserta didik harus menuntaskan sejumlah materi yang dianggap oleh peserta didik adalah materi yang abstrak karena tidak dapat diamati dengan mudah oleh mata telanjang $(62,5 \%)$. Selain itu, dalam konten materi terdapat istilah-istilah yang bagi guru 
sulit untuk diingat, terlebih lagi istilah-istilah yang berkaitan dengan ilmu kimia sel $(12,5 \%)$.

Faktor materi ajar yang dirasa sulit bagi guru selama proses pembelajaran adalah mengaitkan antara organel sel yang satu dengan organel sel yang lainnya dalam mekanisme transport membran $(25 \%)$.

Ahmadi dan Supriyono berpendapat bahwa guru tidak bisa menjadi fasilitator yang baik akan berakibat pada ketidak mampuan guru untuk memahami standar kompetensi yang dimiliki peserta didik. Guru juga tidak memiliki metode yang bervariasi, sehingga dengan materi yang sulit dipahami, ditambah dengan metode yang membuat peserta didik bosan, hal ini menjadi fakor yang mengakibatkan peserta didik mengalami kesulitan belajar.

\section{Faktor pemilihan model/matode pembelajaran}

Di lima SMA Negeri yang menjadi lokasi penelitian ini, diketahui bahwa kelima sekolah tersebut telah melaksanakan kurikulum 2013. Dalam kurikulum 2013, paradigma pembelajaran tidak lagi berpusat pada guru melainkan pada peserta didik. Oleh karena itu, guru selaku fasilator pembelajaran hendaknya mampu memilih model/metode pembelajaran yang mampu membuat peserta didik manjadi aktif mencari tahu dan mengumpulkan informasi pembelajaran.
Kemampuan guru dalam memilih model/metode pembelajaran termasuk dalam kompetensi prdagogik dimana dengan kemampuannya dalam merencanakan pembelajaran menggunakan model pembelajaran tertentu, peserta didik dapat termotivasi semnagat belajarnya sehingga pembelajaran di kelas menjadi aktif dan keterampilan peserta didik dapat meningkat.

Fakta penelitian yang ditemukan di lapangan bahwa dalam pokok bahasan struktur dan fungsi sel, guru masih kesulitan dalam menentukan model/metode pembelajaran yang bervariaasi dan sesuai untuk pokok bahasan tersebut. Oleh sebab itu, 50\% guru di SMA Negeri se-Kota Bima menggunakan metode diskusi dengan kelompok besar, $20 \%$ menggunakan metode ceramah, dan $30 \%$ guru menggunakan metode praktikum di laboratorium.

Dalam hasil penelitiannya, Rahmadani, dkk (2017) menyatakan bahwa pemilihan metode pembelajaran menjadi faktor ketiga yang menjadi penyebab keslitan belajar peserta didik. Penetapan model, metode dan strategi mengajar yang menurut tinjauan psikologis harus sesuai dengan jenis dan sifat meteri, tugas yang akan diberikan kepada siswa dan situasi belajar mengajar yang diharapkan. Metode pembelajaran yang baik adalah metode yang sesuai dengan materi yang akan disampaikan, menyenangkan, sesuai 
dengan kondisi siswa, sarana dan prasarana yang tersedia serta sesuai dengan tujuan pembelajaran yang ditetapkan sehingga bisa dilihat apakah metode yang diterapkan efektif bagi proses pembelajaran yang dilakukan. Pemilihan metode pembelajaran yang tepat merupakan salah satu hal yang mutlak dilakukan oleh guru Syah (2008, dalam Rahmadani, dkk, 2017).

Dikemukakan oleh Umar (2016) bahwa penyusunan perencanaan pembelajaran oleh guru masih dirasa cukup susah, terutama dalam memilih model pembelajaran yang sesuai karena harus dicocokkan dengan materi ajar dan media yang digunakan dalam belajar. Terkadang beberapa guru telah memilih metode pembelajaran yang dinilai sesuai, namun pada tahap implementasi tidak dapat digunakan secara efektif karena tidak sinkron dengan komponen lainnya. Dalam situasi itu, guru cenderung kembali ke metode ceramah mulai dari awal hingga akhir pembelajaran. Padahal dalam penerapannya, model pembelajaran seperti model discovery learning dan problem based lerning yang disarankan pengggunaaannya dalam kurikulum 2013 sangat sesuai untuk diterapkan pada pokok bahasan struktur dan fungsi sel melalui pendekatan saintifik. Model pembelajaran berbasis masalah (problem based learning) dengan pendekan saintifik memberikan peluang dari mulai kegiatan pendahuluan agar dapat menggugah timbulnya pertanyaan pada diri siswa. Kegiatan inti ditujukan untuk terkonstruksinya konsep, hukum atau prinsip oleh siswa dengan bantuan dari guru. Kegiatan penutup ditujukan untuk memperkuat konsep yang telah dibangun oleh siswa serta merayakan usaha dan kerja keras siswa agar tumbuh motivasi, rasa menghargai, dan percaya diri (Jayanti, dkk, 2015). Dengan memilih model pembenalajaran yang tepat seperti itu, maka materi yang dirasa sulit dalam menjadi metari yang menyenangkan dan mudah untuk dipahami oleh siswa.

\section{Faktor sarana dan prasarana pembelajaran}

Pemilihan model/metode pembelajaran tertentu mengharuskan guru menyediakan media pembelajaran untuk membantu memfasilitasi transfer informasi dari guru ke peserta didik, maupun dari peserta didik ke sesama peserta didik. Dalam hal ini, ketersediaan sarana dan prasaran sekolah meliputi adanya proyektor dan laboratorim beserta kelengkapan alat dan bahan praktikum menjadi salah satu faktor kesulitan guru dalam pembelajaran biologi pokok bahasan sel karena materi yang abstrak. Sebanyak $78 \%$ responden guru menggunakan media visual dengan memanfaatkan sarana proyektor untuk membantu siswa memahami struktur sel, struktur organel-organel sel, serta mekanisme 
transport membran. Dari penggunaan media visul tersebut, kebanyakan guru (64\%) menggunakan slide gambar dari power point presentation dan juga video untuk menyampaikan materi ajar, $36 \%$ guru menggunakan LKS bergambar sebagai alat bantu dalam kegiatan diskusi kelompok. Alasan yang dikemukakan responden dengan memilih menggunakan media power point presentation adalah karena tidak tersedianya alat laboratorium yang mendukung untuk melakukan pengamatan sel secara langsung. Hal postif dari penggunaan media visual selama kegiatan pembelajaran adalah sebanyak $38, \%$ peserta didik merasa bahwa jika media yang digunakan oleh guru adalah powerpoint yang disandingkan dengan media gambar, mak apeserta didik lebih mudah mengingat apa yang sudah disampaikan oleh guru (Karim, 2017)

Responden lain sebanyak $22 \%$ menggunakan prepatar sel segar untuk mengamati secara langsung struktur sel dan organelnya, serta mekanisme transport membran. Namun dalam aplikasinya, kegiatan ini cukup banyak menyita waktu pembelajaran dan menimbulkan sejumlah kendala. Tersitanya waktu selama kegiatan praktikum dari yang telah dialokasikan dalam rencana pelaksanaan pembelajaran disebakan karena peserta didik lebih sulit untuk diorganisasikan, proses meyediakan sediaan preparat yang cukup lama, kegagalan saat mengisolasi preparat, dan waktu pengamatan yang tidak dapat diprediksi jika pencahayaan terbatas. Kendala lain yang juga timbul saat praktikum di laboratorium adalah terbatasnya keterampilan siswa menggunakan alat praktikum serta tidak tersedianya laboran yang membantu guru dan peserta didik selama praktikum berlangsung.

Sesuai dengan amanat dalam dokumen kurikulum 2013 bahwa pada kompetensi inti 4 merupakan ranah psikomotorik yang dalam penerapannya diharapkan mampu melatik keteranpilan motorik peserta didik, salah satunya yakni dalam menggunakan alat laboratorium. Namun faktanya bahwa beberapa SMA Negeri di Kota Bima tidak menyediakan sarana dan prasarana laboratirium yang memadai. Hal ini menjadi salah satu faktor kesulitan guru dalam mengimplementaskan kompetensi dasar 4.1 dan 4.2 pada pokok bahasan struktur dan fungsi sel. Padahal, dalam penelitian yang dilakuakn oleh Wahyu (2011), diketahui bahwa $70 \%$ peserta didik mengaku lebih suka melakukan praktikum daripada hanya melihat temannya yang melakukan praktikum, serta dari aspek motivasi belajar saat praktikum, 77,5\% peserta didik mengaku semangat saat praktikum, $56 \%$ peserta didik mempunyai motivasi untuk bertanya. Mengetahui hal tersebut, sangat jelas dikatakan oleh Hasibuan 
(2011, dalam Rahmadani, dkk, 2017) bahwa kurangnya ketersediaan media pembelajaran di sekolah merupakan hal yang sangat perlu diperhatikan oleh kalangan sekolah, masyarakat dan pemerintah.

\section{Faktor jenis evaluasi pembelajaran}

Menurut Undang-Undang Republik Indonesia Nomor 14 Tahun 2005, guru adalah pendidikan profesional dengan tugas utama mendidik, mengajar, membimbing, mengarahkan, melatih, menilai, dan mengevaluasi peserta didik pada pendidikan anak usia dini jalur pendidikan formal, pendidikan dasar, dan pendidikan menengah. Oleh karena itu, kegiatan evaluasi pembelajaran menjadi bagian yang tidak dapat dipidahkan dati tugas seorang guru.

Kurikulum 2013 menekankan penilaian autentik sebagai bentuk evaluasi proses dan hasil belajar. Namun, 71\% guru-guru biologi yang menjadi responden dalam penelitian ini masih menggunakan penilaian konvensional dalam mengevaluasi peserta didik pada pokok bahasan struktur dan fungsi sel. Penilaian yang dilakukan pun tidak jauh berbeda dengan pokok bahasan lain pada mata pelajaran biologi. Hal ini terkendala pada penilaian proses pembelajaran dimana guru hanya menilai hasil belajar melalui tes hasil belajar dengan soal essay ataupun pilihan ganda biasa. Para guru merasa kesulitan dalam menyusun berbagai bentuk penilaian autentik karena belum terbiasa membuatnya.

Berdasarkan hasil penelitian Umar (2016) diketahui bahwa alasan guru mengalami kesulitan dalam melakukan evaluasi pembelajaran karena objek penilaian yang kompleks meliputi penilaian pengetahuan, sikap dan keterampilan. Dimana kesulitan mengimplementasi evaluasi autentik disebabkan karena guru tidak terlatih menilai komponen penilaian yang berdiri sendiri dengan sistem predikat.

\section{KESIMPULAN}

Berdasarkan hasil penelitian dapat disimpulkan bahwa terdapat empat faktor kesulitan guru dalam melaksanakan pembelajaran biologi pokok bahasan struktur dan fungsi sel di SMA Negeri se-Kota Bima. Keempat faktor tersebut yaitu faktor kesukaran materi ajar, faktor pemlihan model/metode pembelajaran, faktor saran dan prasarana pembelajaran, dan faktor jenis evaluasi pembelajaran.

\section{DAFTAR PUSTAKA}

Ahmadi, A \& Supriyono, W. (2004). Psikologi Belajar. Jakarta: Rineka Cipta.

Dokumen Kurikulum 2013. (2013). Kompetensi Dasar Sekolah Menengah Atas (SMA)/Madrasah Aliyah (MA). (online): $\quad$ http://riau.kemenag.go .id/file/file/informasipenting/gqwr1401 
678713. pdf, diakses tanggal 1 Mei 2013.

Jayanti, M. I., Jufri, A. W., \& Ramdani, A. (2015). Pengembangan Perangkat Model Pembelajaran Kuantum Berbasis Masalah dengan Pendekatan Saintifik. Jurnal Penelitian Pendidikan IPA, 1(2).

Karim, I.E. (2017). Kajian Deskriptif Faktor yang Menyebabkan Kesulitan Belajar Biologi pada Peserta Didik Kelas X di Kecamatan Serpong. Skripsi, UIN Syarif Hidayatullah Jakarta.

Nurainun, (2014) Analisis Kesulitan Guru Biologi dalam Melaksanakan Pembelajaran Materi Bioteknologi di SMP Se Kabupaten Aceh Tamiang. Masters thesis, UNIMED.

Rahmadani, W., Harahap, F., \& Gultom, T. (2017). Analisis Faktor Kesulitan Belajar Biologi Siswa Materi Bioteknologi di SMA Negeri Se-Kota Medan. Jurnal Pendidikan Biologi, 6(2).

Umar, U. (2017). Kesulitan Guru DALAM Pembelajaran Pendidikan Agama Islam dan Budi Pekerti Berdasarkan Kurikulum 2013 di SMP Negeri 6 Kota Makassar. Lentera Pendidikan: Jurnal Ilmu Tarbiyah dan Keguruan, 19(2), 182-195.

Undang-Undang Republik Indonesia Nomor 20 Tahun 2003 tentang Sistem Pendidikan Nasional.

Undang-Undang Republik Indonesia Nomor 14 Tahun 2005 tentang Guru dan Dosen. 2006.

Wahyu, E.F.I. (2011). Analisis Permasalahan Penyebab Kesulitan Peserta Didik dalam Praktikum Pemeriksaan Urin di
MA Al-Irsyad Gajah Demak Tahun Pelajaran 2010/2011. Skripsi, IAIN Walisongo. 